\title{
MANAJEMEN OTONOMI PENDIDIKAN DI INDONESIA
}

\author{
Emmi Kholilah Harahap, M. Pd.I \\ Dosen STAI Ma'arif Jambi \\ Dosen Luar Biasa IAIN Sulthan Thaha Saifuddin Jambi \\ 082365461753
}

\begin{abstract}
Education decentralization means that the delegation of powers and wider authority to the regions in planning and making their own decisions in addressing the problems faced in the field of education.Education decentralization provides the authority to school as known as education autonomy. That authority gives the wider space to the school in managing natural and human resources based on the regional potential. Education autonomy does not stop at the local district / city level but to the level of the school as the spearhead of education. The transfer of authority at the school level can help the school in making expansion program direction based on the regional condition and potential.
\end{abstract}

Key words: regional autonomy, decentralization, and education

\begin{abstract}
Abstrak
Desentralisasi pendidikan berarti terjadinya pelimpahan kekuasaan dan wewenang yang lebih luas kepada daerah untuk membuat perencanaan dan mengambil keputusannya sendiri dalam mengatasi permasalahan yang dihadapi di bidang pendidikan. Desentralisasi pendidikan memberikan kewenangan kepada sekolah yang dikenal dengan otonomi pendidikan atau sekolah. Kewenangan tersebut memberikan ruang gerak yang lebih luas kepada sekolah untuk mengelola sumber daya alam dan sumber daya manusia sesuai dengan potensi daerah yang ada. Otonomi dibidang pendidikan tidak berhenti pada daerah tingkat kabupaten/kota tetapi sampai pada tingkat sekolah sebagai ujung tombak penyelenggaraan pendidikan. Dengan adanya pengalihan kewenangan pada level sekolah, maka sekolah diharapkan mampu menentukan arah pengembangan program yang sesuai dengan kondisi dan potensi daerah yang ada.
\end{abstract}

Kata Kunci: Otonomi Daerah, Disentralisasi, dan Pendidikan

\section{Pendahuluan}

Dunia telah mengalami perubahan yang sangat berarti, terlebih dengan dideklarasikannya globalisasi yang menempatkan demokrasi menjadi acuan utama dalam membangun suatu bangsa dan negara. Miftah Thoha dalam

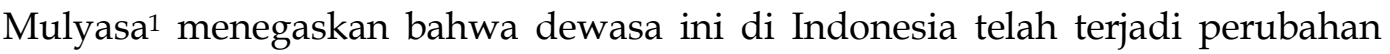
paradigma manajemen pemerintahan, yaitu: 1) dari orientasi manajemen pemerintahan yang sarwa negara menjadi berorientasi pasar, 2) dari orientasi manajemen pemerintahan yang otorian menjadi berorientasi demokrasi, 3) dari sentralisasi kekuasaan menjadi desentralisasi kekuasaan, dan 4) dari sistem pemerintahan yang membatasi pada batas-batas dan aturan-aturan yang mengikat negara yag jelas menjadi tatanan pemerintahan yang cenderung boundaryless organization. Dengan memperhatikan paradigma baru, maka

${ }^{1}$ E. Mulyasa, Manajemen Berbasis Sekolah, Konsep Strategi dan Implementasi, (Bandung: Remaja Rosdakarya, 2012), hal. 19. 
demokrasi dan desentralisasi merupakan unsur yang sangat penting dan strategis.

Desentralisasi dimulai dengan diberlakukannya Undang-Undang Nomor 32 Tahun 2004 tentang Pemerintahan Daerah, dimana sejumlah kewenangan telah diserahkan oleh pemerintah pusat kepada pemerintah daerah untuk melakukan kreasi, inovasi, dan improvisasi dalam upaya pembangunan daerahnya, termasuk juga dalam bidang pendidikan. Desentralisasi pendidikan secara resmi dimulai dengan diberlakukannya Undang-Undang Nomor 20 Tahun 2003 tentang Sistem Pendidikan Nasional. ${ }^{2}$

Menurut Hasbullah ${ }^{3}$ bentuk otonomi dalam bidang pendidikan berbeda dengan otonomi dibidang lainnya. Otonomi dibidang pendidikan tidak berhenti pada daerah tingkat kabupaten/kota tetapi sampai pada tingkat sekolah sebagai ujung tombak penyelenggaraan pendidikan. Dengan adanya pengalihan kewenangan pada level sekolah, maka sekolah diharapkan mampu menentukan arah pengembangan program yang sesuai dengan kondisi dan potensi daerah yang ada. Otonomi pendidikan merupakan upaya pemerintah untuk memajukan setiap sekolah. Sekolah mandiri dengan memberdayakan potensi sumber daya manusia dan potensi kearifan lokal menjadi sekolah yang bermutu.

Sejak Tahun 20034 Pemerintah telah merumuskan paradigma manajemen pendidikan berbasis sekolah/madrasah, sebuah paradigma manajemen pendidikan yang mengarusutamakan keterlibatan masyarakat dalam memformulasikan kebijakan-kebijakan pendidikan. Manajemen Berbasis Sekolah atau yang lebih dikenal dengan MBS merupakan salah satu upaya pemerintah dalam meningkatkan kualitas pendidikan dengan otonomi yang diberikan kepada sekolah untuk menentukan kebijakan sekolah dalam rangka meningkatkan mutu, efisiensi dan pemerataan pendidikan sehingga kebutuhan dan kepentingan masyarakat dapat terakomodasi sekaligus memberdayakan masyarakat secara efektif. ${ }^{5}$

\section{Konsep Otonomi Pendidikan}

Otonomi atau autonomy berasal dari bahasa Yunani autos yang berarti sendiri, dan nomos yang berarti Hkum atau aturan. Dalam konteks etimologis ini, beberapa penulis memberikan pengertian tentang otonomi. Otonomi diartikan sebagai 'perundangan sendiri, 'perundangan sendiri', 'mengatur atau rnemerintah sendiri' Tilaar lebih lanjut mengemukakan bahwa menurut

2 Undang-Undang Nomor 32 Tahun 2004 tentang Pemerintahan Daerah dan UndangUndang Nomor 20 Tahun 2003 tentang Sistem Pendidikan Nasional.

3 Hasbullah. Otonomi Pendidikan: Kebijakan Otonomi Daerah Dan Implikasinya Terhadap Penyelenggaraan Pendidikan (Jakarta: PT Raja Grafindo Persada, 2007), hal. 66.

4 Dalam UU No. 20 Tahun 2003 tentang Sistem Pendidikan Nasional pasal 51 disebutkan bahwa "Pengelolaan satuan pendidikan anak usia dini, pendidikan dasar, dan pendidikan menengah dilaksanakan berdasarkan standar pelayanan minimal dengan prinsip manajemen berbasis sekolah/madrasah"

${ }^{5}$ E. Mulyasa, Op. Cit., hal. 11.

RI'AYAH, Vol. 01, No. 02 Juli-Desember 2016 
perkembangan sejarahnya di Indonesia, otonomi selain mengandung arti 'perundangan', juga mengandung pengertian ‘pemerintahan'. ${ }^{6}$

Secara konseptual banyak konsep tentang otonomi yang diberikan oleh para pakar dan penulis, di antaranya Suparman ${ }^{7}$ mengartikan otonomi sebagai hak mengatur dan memerintah daerah sendiri, hak mana diperoleh dari pemerintah pusat. otonomi daerah merupakan kebebasan untuk memelihara dan memajukan kepentingan khusus daerah, dengan keuangan sendiri, menentukan hukum sendiri, dan pemerintahan sendiri. otonomi juga diartikan sebagai hak dan wewenang untuk mengatur dan mengurus rumah tangga daerah. otonomi mempunyai makna kebebasan dan kemandirian, tetapi bukan kemerdekaan. Kebebasan yang terbatas atau kemandirian itu adalah wujud pemberian kesempatan yang harus dipertanggungjawabkan. Pada hakikatnya otonomi daerah adalah (1) hak mengurus rumah tangga sendiri bagi suatu daerah otonom; (2) dalam kebebasan menjalankan hak mengurus dan mengatur rumah tangga sendiri, daerah tidak dapat menjalankan hak dan wewenang otonominya itu di luar batas-batas wilayah daerahnya; (3) daerah tidak boleh mencampuri hak mengatur dan mengurus rumah tangga daerah lain sesuai dengan wewenang pangkal dan urusan yang diserahkan kepadanya; dan (4) otonomi tidak membawahi otonomi daerah lain, hak mengatur dan mengurus rumah tangga sendiri tidak merupakan subordinasi hak mengatur dan mengurus rumah tangga daerah lain.

Menurut UU Nomor 32 Tahun 2004 tentang Pemerintahan Daerah pada Pasal 1 ayat (5) dikemukakan bahwa otonomi daerah adalah hak, wewenang, dan kewajiban daerah otonom untuk mengatur dan mengurus sendiri urusan pemerintahan clan kepentingan masyarakat setempat sesuai dengan peraturan perundang-undangan.

Daerah Otonom di sini dimaksudkan adalah kesatuan masyarakat hukum yang mempunyai batas-batas wilayah yang berwenang mengatur clan mengurus urusan pemerintahan dan kepentingan masyarakat setempat menurut prakarsa sendiri berdasarkan aspirasi masyarakat dalam sistem Negara Kesatuan Republik Indonesia. Dari beberapa konsep dan batasan di atas, otonomi daerah jelas menunjuk pada kemandirian daerah, di mana daerah diberikan kewenangan untuk mengatur dan mengurus rumah tangganya sendiri tanpa atau mengupayakan seminimal mungkin adanya campur tangan atau intervensi pihak lain atau pemerintah pusat clan pemerintah di atasnya. Dengan otonomi tersebut, daerah bebas untuk berimprovisasi, mengekspresikan dan mengapresiasikan kemampuan dan potensi yang dimiliki, mempunyai

6 Tilaar, Manajemen Pendidikan Nasional, Kajian Pendidikan Masa Depan, (Bandung: Remaja Rosda Karya), hal. 22.

7 R. M. Suparman, Studi Pengembangan Kemampuan Dareah dalam Pendidikan, (Jakarta: Balitbangdikbud, t.th), hal. 10.

RI'AYAH, Vol. 01, No. 02 Juli-Desember 2016 
kebebasan berpikir dan bertindak, sehingga bisa berkarya sesuai dengan kebcbasan yang dimilikinya.

Otonomi daerah sebagai salah satu bentuk desentralisasi pemerintahan, pada hakikatnya ditujukan untuk memenuhi kepentingan bangsa secara keseluruhan, yaitu upaya untuk lebih mendekati tujuan-tujuan penyelenggaraan pemerintahan untuk mewujudkan cita-cita masyarakat yang lebih baik, suatu masyarakat yang lebih adil dan lebih sejahtera.

Desentralisasi diartikan sebagai penyerahan wewenang pemerintahan oleh pemerintah kepada daerah otonom untuk mengatur dan mengurus urusan pemerintahan dalam sistem Negara Kesatuan Republik Indonesia (Pasal 1 ayat (7) UU Nomor 32 Tahun 2004). Tentang desentralisasi ini ada beberapa konsep yang dikemukakan oleh para ahli sebagai berikut: Desentralisasi merupakan penyerahan wewenang dari tingkat pemerintahan yang lebih tinggi kepada pemerintahan yang lebih rendah, baik yang menyangkut bidang legislatif, judikatif, atau administratif.

Desentralisasi sebagai suatu sistem yang dipakai dalam bidang pemerintahan merupakan kebalikan dari sentralisasi, di mana sebagian kewenangan pemerintah pusat dilimpahkan kepada pihak lain untuk dilaksanakan. Desentralisasi tidak hanya berarti pelimpahan wewenang dari pernerintah pusat ke pemerintah yang lebih rendah, tetapi juga pelimpahan beberapa wewenang pemerintahan ke pihak swasta dalam bentuk privatisasi. Desentralisasi adalah sehagai pengakuan atau penyerahan wewenang oleh badan-badan umurn yang lebih rendah untuk secara mandiri dan berdasarkan pertimbangan kepentingan sendiri mengambil lceputusan pengaturan pernerintahan, serta struktur wewenang yang terjadi dari hal itu.

Pengertian desentralisasi pada dasarnya mempunyai makna bahwa melalui proses desentralisasi unisan-urusan pemerintahan yang semula termasuk wewenang dan tanggung jawab pemerintah pusat sebagian diserahkan kepada pernerintah daerah agar menjacli urusan rumah tangganya sehingga urusan tersebut beralih kepada dan menjadi wewenang clan tanggung jawab pernerintah daerah.

Desentralisasi atau mendesentralisasi pemerintahan bisa berarti merestrukturisasi atau mengatur kembali kekuasaan sehingga terdapat suatu sistem tanggung jawab bersama antara institusi-institusi pemerintah tingkat pusat, regional, maupun lokal sesuai dengan prinsip subsidiaritas. Sehingga meningkatkan kualitas keefektifan yang menyeluruh dari sistem pemerintahan, dan juga meningkatkan otoritas dan kapasitas tingkat subnasional.

Dari beberapa konsep di atas, dapat disimpulkan bahwa desentralisasi merupakan adanya penyerahan wewenang urusan-urusan yang semula menjacli kewenangan pemerintah pusat kepada pemerintah daerah untuk melaksanakan urusanurusan tersebut. Secara politis, desentralisasi dalam pengertian devolusi dilakukan untuk memenuhi tuntutan golongan minoritas yang menuntut

RI'AYAH, Vol. 01, No. 02 Juli-Desember 2016 
otonomi dalarn wilayahnya. Semakin tinggi praktikpraktilc diskriminasi, akan semakin kuat menciptakan tuntutan akan otonomi.

Desentralisasi secara luas diharapkan untuk mengurangi kepadatan beban kerja di pernerintah pusat. Sementara itu, di lain pihak mengemukakan bahwa desentralisasi merupakan suatu cara untuk meningkatkan kemampuan aparat pemerintah clan incmperoleh informasi yang lebih baik mengenai keadaan daerah, untuk menyusun program-program daerah secara lebih responsif dan untuk mengantisipasi secara cepat manakala prrsoalan-persoalan timbul dalam pelaksanaan.

Desentralisasi juga dapat dipakai sebagai alat untuk memobilisasi dukungan terhadap kebijakan pembangunan nasional dengan menginformasikannya kepada masyarakat (Lurah untuk menggalang partisipasi di dalam perencanaan pembangunan dan pelaksanaannya di daerah. Partisipasi lokal dLipat digalang melalui keterlibatan dari berbagai kepentingan sepcrti kepentingan-kepentingan politik, agama, suku, kelompok-kelompok profesi di dalam proses pembuatan kebijakan pembangunan oleh pemerintah daerah.

Bagaimanapun, secara politis keberadaan pemerintah daerah sangat penting untuk mengakomodasikan kebutuhan-kebutuhan daerah. Menurut UU Nomor 32 Tahun 2004 pada Pasal 7 ayat (1) dikemukakan bahwa kewenangan daerah mencakup kewenangan dalam seluruh bidang pemerintahan, kecuali kewenangan dalam bidang politik luar negeri, pertahanan keamanan, peradilan, fiskal/moneter, dan agama, serta kewenangan lain yang diatur secara khusus. Selain itu, semuanya menjadi kewenangan daerah, termasuk salah satunya bidang pendidikan. Tujuan pemberian kewenangan dalam penyelenggaraan otonomi daerah adalah untuk meningkatkan kesejahteraan rakyat, pemerataan dan keadilan, demokratisasi clan penghormatan terhadap budaya lokal, serta memerhatikan potensi dan keanekaragaman daerah.

Kewenangan pengelolaan pendidikan berubah dari system sentralisasi ke sistem desentralisasi. Desentralisasi pendidikan berarti terjadinya pelimpahan kekuasaan dan wewenang yang lebih luas kepada daerah untuk membuat perencanaan dan mengambil keputusannya sendiri dalam mengatasi permasalahan yang dihadapi di bidang pendidikan. Berdasarkan PP Nomor 25 Tahun 2000 tentang Kewenangan Pemerintah dan Kewenangan Provinsi sebagai daerah Otonom, pada kelompok bidang pendidikan dan kebudayaan disebutkan bahwa kewenangan pemerintah meliputi hal-hal sebagai berikut: penetapan standar kompetensi siswa dan warga belajar, serta pengaturan kurikulum nasional dan penilaian hasil belajar secara nasional, serta pedoman pelaksanaannya; penetapan standar materi pelajaran pokok; penetapan persyaratan perolehan dan penggunaan gelar akademik; penetapan pedoman pembiayaan penyelenggaraan pendidikan; penetapan persyaratan penerimaan, perpindahan, sertifikasi siswa, warga belajar dan mahasiswa; penetapan persyaratan peningkatan/zoning, pencarian, pemanfataan, pemindahan,

RI'AYAH, Vol. 01, No. 02 Juli-Desember 2016 
penggandaan, sistem pengamanan dan kepemilikan benda cagar budaya, serta persyaratan penelitian arkeologi; pemanfaatan hasil penelitian arkeologi nasional serta pengelolaan museum nasional, galeri nasional, pemanfaatan naskah sumber arsip, clan monumen yang diakui secara internasional; penetapan kalender pendidikan dan jumlah jam belajar efektif setiap tahun bagi pendidikan dasar, menengah, dan luar sekolah; pengaturan dan pengembangan pendidikap tinggi, pendidikan jarak jauh, serta pengaturan sekolah internasional; pembinaan dan pengembangan bahasa clan sastra Indonesia.

Sementara itu, kewenangan pemerintah provinsi meliputi hal-hal sebagai berikut: penetapan kebijakan tentang penerimaan siswa dan mahasiswa dari masyarakat minoritas, terbelakang, dan/ atau tidak mampu; penyediaan bantuan pengadaan buku pelajaran pokok/ modul pendidikan untuk taman kanak-kanak, pendidikan dasar, pendidikan menengah, dan pendidikan luar sekolah; mendukung/membantu penyelenggaraan pendidikan tinggi selain pengaturan kurikulum, akreditasi, dan pengangkatan tenaga akademis; pertimbangan pembukaan clan penutupan perguruan tinggi; penyelenggaraan sekolah luar biasa dan balai pelatihan clan/ atau penataran guru; penyelenggaraan museum provinsi, suaka peninggalan sejarah, kepurbakalaan, kajian sejarah clan nilai tradisional, serta pengembangan bahasa dan budaya daerah.

Desentralisasi pendidikan merupakan sebuah sistem manajemen untuk mewujudkan pembangunan pendidikan yang menekankan pada kebhinnekaan. Untuk pendidikan itu sendiri ada beberapa hal yang harus dipenuhi dalam pelaksanaan desentralisasi pendidikan, yaitu (1) pola dan pelaksanaan manajemen harus demokratis; (2) pemberdayaan masyarakat harus menjadi tujuan utama; (3) peran serta masyarakat bukan hanya pada staheholders, tetapi harus menjadi bagian mutlak dari sistem pengelolaan; (4) pelayanan harus lebih cepat, efisien, efektif, melebihi pelayanan era sentralisasi demi kepentingan peserta didik dan rakyat banyak; dan (5) keanekaragaman aspirasi dan nilai serta norma lokal harus dihargai dalam kerangka dan demi penguatan sistem pendidikan nasional.

Dalam praktiknya, desentralisasi pendidikan berbeda dengan desentralisasi bidang pemerintahan lainnya, kalau desentralisasi bidang-bidang pemerintahan lain berada pada pemerintahan di tingkat kabupaten/kota, maka desentralisasi di bidang pendidikan tidak berhenti pada tingkat kabupaten/kota, tetapi justru sampai pada lembaga pendidikan atau sekolah sebagai ujung tombak pelaksanaan pendidikan. Dalam praktik desentralisasi pendidikan itulah maka dikembangkanlah yang dinamakan Manajemen Berbasis Sekolah (MBS).

Desentralisasi penyelenggaraan pendidikan dan manajemen berbasis sekolah, sebenarnya merupakan kecenderungan internasional yang dipraktikkan di banyak negara, dan untuk Indonesia merupakan salah satu upaya untuk memperbaiki mutu pendidikan dan sumber daya manusia yang belakangan ini

RI'AYAH, Vol. 01, No. 02 Juli-Desember 2016 
dirisaukan banyak pihak, terutama bila dilihat dari beberapa laporan hasil survei dari lembaga-lembaga independen dunia, menempatkan kualitas sumber daya manusia Indonesia pacla urutan bawah, jauh di bawah negara-negara tetangga seperti Singapur, Malaysia, Thailand, dan bahkan Filipina.

Dalam konteks desentralisasi ini, peran serta masyarakat sangat diperlukan. Aparatur pendidikan baik di pusat maupun di daerah, berperan penting dalam peningkatan peran serta, efisiensi, dan produktivitas masyarakat untuk membangun pendidikan yang mandiri dan profesional. Salah satu sasaran pembangunan adalah mewujudkan desentralisasi daerah yang nyata, dinamis, dan bertanggung jawab. Titik berat desentralisasi diletakkan pada kabupaten/kota. Oleh karena itu, peningkatan kualitas aparatur pendidikan di daerah amatlah mendasar pcranannya, terutama pada lapisan yang terdekat dengan rakyat yang mendapat pelayanan. Efektivitas pelayanan pendidikan pada tingkat akar rumput (grass root) juga penting untuk mendorong partisipasi aktif masyarakat dalam pembangunan pcndidikan. Sebagaimana dikemukakan terdahulu, bahwa desentralisasi di bidang pendidikan berbeda dengan desentralisasi bidang pemerintahan lainnya yang berhenti pada tingkat kabupaten/kota. Di bidang pendidikan justru sampai pada pelaksana teknis atau ujung tombak pendidikan, yaitu sekolah. ${ }^{8}$

\section{Manajemen Otonomi Pendidikan}

Desentralisasi pendidikan memberikan kewenangan kepada sekolah yang dikenal dengan otonomi pendidikan atau sekolah. Kewenangan tersebut memberikan ruang gerak yang lebih luas kepada sekolah untuk mengelola sumber daya alam dan sumber daya manusia sesuai dengan potensi daerah yang ada.

Otonomi dibidang pendidikan tidak berhenti pada daerah tingkat kabupaten/kota tetapi sampai pada tingkat sekolah sebagai ujung tombak penyelenggaraan pendidikan. Dengan adanya pengalihan kewenangan pada level sekolah, maka sekolah diharapkan mampu menentukan arah pengembangan program yang sesuai dengan kondisi dan potensi daerah yang ada.

Menurut Umiarso dan Gojali ${ }^{9}$ Konsep penyelenggaraan pendidikan yang bersifat desentralisasi dikenal dengan manajemen berbasis sekolah yang merupakan perubahan paradigma pengelolaan pendidikan yang semula berpusat pada pemerintah pusat beralih ke pengelolaan pendidikan pada pola manajemen dimana sekolah tersebut yang mengelolanya.

Manajemen Berbasis Sekolah (MBS) merupakan terjemahan dari "schoolbased management" istilah ini pertama kali muncul di Amerika Serikat ketika

8 E. Mulyasa, Op. Cit., hal. 23.

9 Umiarso dan Imam Ghozali, Manajemen Mutu Sekolah di Era Otonomi Pendidikan, (Jogjakarta: IRCiSoD, 2010), hal. 28.

RI'AYAH, Vol. 01, No. 02 Juli-Desember 2016 
masyarakat mulai mempertanyakan relevansi pendidikan dengan tuntutan dan perkembangan masyarakat setempat ${ }^{10}$. Paradigma manajemen ini muncul ketika masyarakat Amerika Serikat sudah tidak lagi mendapatkan manfaat yang signifikan atas keberadaan lembaga pendidikan, dimana output pendidikan cenderung menjauh dari realitas sosialnya.

Sehingga pendidikan harus direformasi menuju pendidikan yang mampu melibatkan masyarakat dan memiliki dampak langsung atas output pendidikan. "Manajemen Pendidikan Berbasis Sekolah merupakan paradigma baru pendidikan, yang memberikan otonomi luas pada tingkat sekolah (pelibatan masyarakat) dalam kerangka kebijakan pendidikan nasional, Otonomi yang diberikan agar sekolah leluasa mengelola sumber daya dan sumber dana dengan mengalokasikannya sesuai dengan prioritas kebutuhan, serta lebih tanggap terhadap kebutuhan setempat. Pelibatan masyarakat dimaksudkan agar mereka lebih memahami, membantu dan mengontrol pengelolaan pendidikan. ${ }^{11}$

Dari definisi diatas dapat dipahami bahwa MBS merupakan sebuah paradigma manajemen yang mengarusutamakan otonomi dan pelibatan masyarakat, otonomi pendidikan yang dimaksud adalah sebuah upaya untuk memberikan ruang yang seluas-luasnya kepada sekolah untuk mengembangkan dan mengelola institusinya, selain itu juga institusi pendidikan diharapkan mampu menemukan relevansinya dengan kebutuhan dan kepentingan masyarakat setempat dengan melibatkan masyarakat dalam pengambilan dan pengawalan kebijakan pendidikan.

Menurut Danim ${ }^{12}$, kebijakan Manajemen Berbasis Sekolah di Indonesia baru dimulai sejak tahun 1999/2000, yaitu dengan peluncuran dana bantuan yang disebut dengan Bantuan Operasional Manajemen Mutu (BOMM). Dana tersebut disetor langsung ke rekening sekolah, tidak melalui alur birokrasi pendidikan di atasnya.

Menurut Umiarso dan Gojali13 ${ }^{13}$ (2010:81) adapun Kementerian Pendidikan Nasional mendeskripsikan bahwa tujuan pelaksanaan MBS adalah meningkatkan mutu pendidikan melalui kemandirian dan inisiatif sekolah dalam mengelola serta memberdayakan sumber daya yang ada yang tersedia; meningkatkan kepedulian warga sekolah dan masyarakat dalam penyelenggaraan pendidikan melalui pengambilan keputusan bersama; meningkatkan tanggung jawab sekolah kepada orang tua, masyarakat, dan pemerintah tentang mutu sekolahnya; serta meningkatkan kompetisi yang sehat antar sekolah tentang mutu pendidikan yang akan dicapai.

10 E. Mulyasa, Op. Cit.,, hal. 24

${ }^{11}$ Ibid

12 Sudarwan Danim, Visi Baru Manajemen Sekolah dari Unit Birokrasi ke Lembaga Akademik. (Jakarta: PT Bumi Aksara, 2006), hal. 28.

13 Umiarso dan Imam Ghozali, Op. Cit., hal. 81

RI'AYAH, Vol. 01, No. 02 Juli-Desember 2016 
Menurut Umiarso dan Gojali ${ }^{14}$ Konsep dasar manajemen berbasis sekolah adalah pengelolaan peningkatan mutu pendidikan yang dilakukan sekolah secara mandiri dengan melibatkan semua pihak yang terkait dengan pendidikan yang biasa disebut dengan otonomi pendidikan atau sekolah. Sehingga dalam proses perencanaan, pelaksanaan dan evaluasi mutu pendidikan di sekolah mampu melibatkan stakeholder sekolah, karena esensi MBS adalah otonomi sekolah dan pengambilan keputusan partisipasif untuk mencapai sasaran mutu pendidikan di sekolah.

Menurut Hasbullah ${ }^{15}$ dalam bidang pendidikan, otonomi akan memberdayakan aparat tingkat daerah dan lokal sehingga memberikan hasil yang lebih baik. Dibidang pendidikan sendiri otonomi diberikan sampai pada tingkat sekolah. Otonomi persekolahan diharapkan memperbaiki pelayanan, menata organisasi sekolah, mencari, mengembangkan dan mendayagunakaan sumber daya pendidikan yang tersedia, serta memperbaiki kinerja sekolah dalam upaya meningkatkan mutu pendidikan sekolah yang bersangkutan.

Menurut Kemendiknas dalam Sujanto ${ }^{16}$ fungsi-fungsi yang dapat didesentralisasikan ke sekolah adalah:

1. Perencanaan dan evaluasi program sekolah. Sekolah diberi kewenangan untuk melakukan perencanaan sesuai dengan kebutuhannya, misalnya kebutuhan untuk meningkatkan mutu sekolah. Sekolah juga diberi wewenang untuk melakukan evaluasi, khususnya evaluasi internal atau evaluasi diri.

2. Pengelolaan kurikulum. Sekolah dapat mengembangkan, namun tidak boleh mengurangi isi kurikulum yang berlaku secara nasional yang dikembangkan oleh Pemerintah Pusat. Sekolah juga diberi kebebasan untuk mengembangkan kurikulum muatan lokal. Menurut Hasbullah ${ }^{17}$ Kurikulum kelembagaan pendidikan yang baik adalah kurikulum kelembagaan pendidikan yang berkembang dari dan untuk masyarakat, yaitu kelembagaan pendidikan yang bersandarkan pada komunitas masyarakat.

3. Pengelolaan proses belajar mengajar. Sekolah diberi kebebasan untuk memilih strategi, metode dan teknik pembelajaran dan pengajaran yang paling efektif sesuai dengan karakteristik mata pelajaran, karakteristik siswa, karakteristik guru dan kondisi nyata sumber daya yang tersedia di sekolah.

4. Pengelolaan ketenagaan. Pengelolaan ketenagaan mulai dari analisis kebutuhan perencanaan, rekrutmen, pengembangan, penghargaan dan sangsi, hubungan kerja hingga evaluasi kinerja tenaga kerja sekolah dapat

14 Ibid., hal. 19.

${ }^{15}$ Hasbullah, Op. Cit., hal. 54-55.

16 Bedjo Sujanto, Manajemen Pendidikan Berbasis Sekolah; Model Pengelolaaan Sekolah di Era Otonomi Daerah, (Jakarta: Sagung Seto, 2007), hal. 36.

17 Hasbullah, Op. Cit., hal. 22.

RI'AYAH, Vol. 01, No. 02 Juli-Desember 2016 
dilakukan oleh sekolah kecuali guru pegawai negeri yang sampai saat ini masih ditangani oleh birokrasi di atasnya.

5. Pengelolaan peralatan dan perlengkapan. Pengelolaan fasilitas seharusnya dilakukan oleh sekolah mulai dari pengadaan, pemeliharaan dan perbaikan hingga pengembangannya. Hal ini didasari oleh kenyataan bahwa sekolahlah yang paling mengetahui kebutuhan fasilitas baik kecukupan, kesesuaian dan kemutakhirannya terutama fasilitas yang sangat erat kaitannya secara langsung dengan proses belajar mengajar.

6. Pengelolaan keuangan. Pengelolaan keuangan, terutama pengalokasian/penggunaan uang sudah sepantasnya dilakukan oleh sekolah. Sekolah juga harus diberi kebebasan untuk melakukan kegiatankegiatan yang mendatangkan penghasilan, sehingga sumber keuangan tidak semata-mata tergantung pada pemerintah.

7. Pelayanan siswa. Pelayanan siswa mulai dari penerimaan siswa baru, pengembangan, pembinaan, pembimbingan, penempatan untuk melanjutkan sekolah atau untuk memasuki dunia kerja hingga pengurusan alumni dari dulu telah didesentralisasikan. Yang diperlukan adalah peningkatan intensitas dan ekstensitasnya. Menurut Umiarso dan Gojali18 Manajemen kesiswaan merupakan salah satu bidang operasional manajemen berbasis sekolah. Manajemen kesiswaan adalah seluruh proses kegiatan yang direncanakan dan diusahakan secara sengaja serta pembinaan secara berkelanjutan terhadap seluruh peserta didik agar dapat mengikuti proses belajar mengajar dengan efektif dan efisien.

8. Hubungan sekolah dan masyarakat. Esensi hubungan sekolah dan masyarakat adalah untuk meningkatkan keterlibatan, kepedulian, kepemilikan dan dukungan dari masyarakat, terutama dukungan moral dan finansial yang dari dulu telah didesentralisasikan. Yang diperlukan adalah peningkatan intensitas dan ekstensitasnya. Menurut Mulyasa ${ }^{19}$ hubungan sekolah dengan masyarakat pada hakikatnya merupakan suatu sarana yang sangat berperan dalam membina dan mengembangkan pertumbuhan pribadi siswa di sekolah.

9. Pengelolaan iklim sekolah. Iklim sekolah yang kondusif-akademik merupakan prasyarat bagi terselenggaranya proses belajar mengajar yang efektif. Lingkungan sekolah yang aman dan tertib, optimisme dan harapan yang tinggi dari warga sekolah, kesehatan sekolah dan kegiatankegiatan yang terpusat pada siswa adalah contoh iklim sekolah yang dapat menumbuhkan semangat belajar siswa. Iklim sekolah sudah merupakan kewenangan sekolah dan yang diperlukan adalah peningkatan intensitas dan ekstensitasnya.

18 Umiarso dan Imam Gojali, Op. Cit., hal. 98.

19 E. Mulyasa, Op. Cit., hal. 50.

RI'AYAH, Vol. 01, No. 02 Juli-Desember 2016 


\section{Pelaksanaan Otonomi Pendidikan dan Solusinya dalam menghadapi kendala}

Pelaksanaan otonomi pendidikan di Indonesia merupakan tugas yang berat, yang harus dilaksanakan. Pemberian otonomi pendidikan tidak cukup hanya diberikan pada tingkat propinsi, kabupaten/ kota, namun idealnya harus sampai pada tingkat sekolah/ unit kerja. Kepala sekolah, guru, tenaga administrasi dan tenaga pelaksana diberi tanggungjawab besar dalam melaksanakan otonomi pendidikan tersebut. Otonomi pendidikan yang benar harus bersifat accountable, artinya kebijakan pendidikan yang diambil harus selalu dipertanggung-jawabkan kepada publik, karena sekolah didirikan merupakan istitusi publik atau lembaga yang melayani kebutuhan masyarakat. Otonomi tanpa disertai dengan akuntabilitas publik bisa menjurus menjadi tindakan yang sewenang-wenang. Berangkat dari ide otonomi pendidikan muncul beberapa konsep sebagai solusi dalam menghadapi kendala dalam pelaksanaan otonomi pendidikan, yaitu :

1. Meningkatkan Manajemen Pendidikan Sekolah

Menurut Wardiman Djajonegoro dalam Sudarwan ${ }^{20}$ bahwa kualitas pendidikan dapat ditinjau dari segi proses dan produk. Pendidikan disebut berkualitas dari segi proses jika proses belajar mengajar berlangsung secara efektif, dan peserta didik mengalami pembelajaran yang bermakna. Pendidikan disebut berkualitas dari segi produk jika mempunyai salah satu ciri-ciri sebagai berikut : a) peserta didik menunjukkan penguasaan yang tinggi terhadap tugas-tugas belajar (learning task) yang harus dikuasai dengan tujuan dan sasaran pendidikan, diantaranya hasil belajar akademik yang dinyatakan dalam prestasi belajar (kualitas internal); b) hasil pendidikan sesuai dengan kebutuhan peserta didik dalam kehidupan sehingga dengan belajar peserta didik bukan hanya mengetahui sesuatu, tetapi dapat melakukan sesuatu yang fungsional dalam kehidupannya (learning and earning); c) hasil pendidikan sesuai atau relevan dengan tuntutan lingkungan khususnya dunia kerja. Menghadapi kondisi ini maka dilakukan pemantapan manajemen pendidikan yang bertumpu pada kompetensi guru dan kesejahteraannya. Menurut Penelitian Simmons dan Alexander bahwa ada tiga faktor untuk meninkatkan mutu pendidikan, yaitu motivasi guru, buku pelajaran dan buku bacaan serta pekerjaan rumah. Dari hasil penelitian ini, tampak dengan jelas bahwa akhir penentu dalam meningkatkan mutu pendidikan tidak pada bergantinya kurikulum, kemampuan manajemen dan kebijakan di tingkat pusat atau pemerintah daerah, tetapi lebih kepada faktor-faktor internal yang ada di sekolah, yaitu peranan guru, fasilitas pendidikan dan pemanfataannya; Kepala Sekolah sebagai top manajemen harus mampu memberdayakan semua 
unit yang dimiliki untuk dapat mengelola semua infrastruktur yang ada demi pencapaian kinerja yang maksimal.

Selain itu, untuk dapat meningkatkan otonomi manajemen sekolah yang mendukung peningkatan mutu pendidikan, Pimpinan Sekolah harus memiliki kemampuan untuk: 1) melibatkan partisipasi dan komitmen dari orangtua dan anggota masyarakat sekitar sekolah untuk merumuskan dan mewujudkan visi, misi dan program peningkatan mutu pendidikan secara bersama-sama; Salah satu tujuan UU No. 20 Tahun 2003 adalah untuk memberdaya-kan masyarakat, menumbuhkan prakarsa dan kreativitas, meningkatkan peran serta masyarakat, termasuk dalam meningkatkan sumber dana dalam penyelenggaraan pendidikan. Melalui otonomi daerah, pengambilan keputusan yang berkaitan dengan penyelenggaraan pendidikan akan semakin erat kaitannya dengan kebutuhan masyarakat. Pembentukan Dewan Pendidikan dan Komite Sekolah dari tingkat propinsi sampai ke tingkat kecamatan sebaiknya terdiri dari tokoh-tokoh masyarakat, orangtua siswa, pakar pendidikan dan sebagainya. Ini merupakan salah satu cara melibatkan masyarakat dalam penyelenggaraan pendidikan Menurut Kepmen Diknas No. 044/U/2002 menyebutkan peran yang harus diemban Dewan Pendidikan dan Komite Sekolah adalah : a) Sebagai Advisory Agency (pemberi pertimbangan); b) Supporting Agency ( pendukung kegiatan layanan pendidikan); 3) Controlling Agency (pengontrol kegiatan layanan pendidikan); dan 4) Mediator atau penghubung atau pengait tali komunikasi antara masyarakat dengan pemerintah dapat merumuskan sasaran program dan indikator pencapaian yang diikuti dengan upaya pemenuhan standar layanan minimal dari seluruh komponen sekolah serta mekanisme untuk mencapai sasaran program tersebut; 3) melaksanakan program "basic skill test" yang hasilnya menggambarkan hasil akhir sebagai dampak diterapkannya model manajemen peningkatan mutu berbasis sekolah; 4) menyusun sendiri perencanaan sekolah baik pada tataran perencanaan strategik (jangka menengah) maupun perencanaan operasional (tahunan) termasuk perencanaan anggaran (RAPBS); 5) dapat mempertanggung jawabkan tingkat keberhasilan pelaksanaan program dalam bentuk laporan akuntabilitas yang dapat dilihat dan diperiksa warga sekolah, orangtua dan masyarakat luas.

2. Membangun Pendidikan Berbasis Masyarakat

Satu hal yang perlu disadari adalah pluralitas masyarakat, budaya, dan geografis Indonesia. Penyeragaman pendidikan masyarakat sama saja artinya penddikan melawan fakta yang ada, pendidikan yang tidak membumi. Jadi secara alamiah, sistem pendidikan yang perlu dibangun dalam era otonomi adalah pendidikan berbasis masyarakat

RI'AYAH, Vol. 01, No. 02 Juli-Desember 2016 
yang plural itu. Pendidikan berbasis masyarakat (community-based education) pada hakekatnya adalah pendidikan yang berasal, berlangsung, dan berorientasi kepada kebutuhan masyarakat. Sasaran akhirnya adalah pemberdayaan masyarakat dengan program-program pendidikan yang menyentuh langsung kehidupan nyata masyarakat setempat.

Kondisi Sumber Daya yang dimiliki setiap daerah tidak merata untuk seluruh Indonesia. Untuk itu, pemerintah daerah dapat melibatkan tokoh-tokoh masyarakat, ilmuwan, pakar berbagai disiplin yang ada di daerah otonomi, terutama yang terdapat di kampus sebagai Brain Trust atau Think Thank untuk turut membangun daerahnya, tidak hanya sebagai pengamat, pemerhati, pengecam kebijakan daerah. Sebaliknya, lembaga pendidikan juga harus membuka diri, lebih banyak mendengan opini publik, kinerjanya dan tentang tanggung jawabnya dalam turut serta memecahkan masalah yang dihadapi masyarakat. Intinya, kebijakan publik di daerah otonomi harus berbasis masyarakat, khusus pembangunan pendidikan dalam rangka peningkatan kualitas sumber daya manusia (SDM) aset dan investasi masa depan daerah otonomi.

3. Pengaturan Kebijakan Pendidikan antara Pusat dan Daerah

Pemerintah Pusat mengurangi campur tangan dalam urusan pendidikan daerah. Pemerintah Pusat hanya diperbolehkan memberikan kebijakan-kebijakan bersifat nasional, seperti standard mutu dan pemerataan. Dengan demikian, pemerintah pusat hanya berperan sebagai fasilitator dan katalisastor. Langkah awal yang perlu dilakukan ke depan adalah mengembalikan fungsi negara dan pemerintahan daerah kepada fungsi yang sebenarnya. Pemerintah sebagai pelayan publik tidak mesti menyentuh secara langsung aspek-aspek kehidupan sosial dan ekonomi masyarakat. Pemerintah hanya berurusan dengan regulasi, membuat "rule of the games" dan menjaga ketentuan-ketentuan itu untuk kelancaran penyelengaraan kegiatan sosial dan ekonomi masyarakat, khusus sektor pendidikan. Untuk Indonesia, perlu suatu model dan pola baru penyelenggaraan manajemen kebijakaan publik, termasuk pelayanan pendidikan dalam era otonomi yang sudah berlangsung beberapa tahun ini. Model dan pola dimaksud berpedoman kepada prinsip efisiensi dan efektivitas kebijakan publik. Menurut Prof. Iman Chourman, model dan pola tersebut hanya dapat diwujudkan melalui tiga hal: Pertama, menerapkan prinsip good governance (Prinisip pengasuhan/pengayoman dan pelayanan yang baik dan benar); kedua, kuatnya motivasi pengabdian/priotisme para abdi negara/penyelenggara negara kepada masyarakat, nusa dan bangsa; ketiga, proses pengambilan keputusan yang berdasarkan consensus semua pihak yang berkepentingan. Dalam manajemen strategik, membangun sebuah konsensus dari stakeholder

RI'AYAH, Vol. 01, No. 02 Juli-Desember 2016 
kunci sehingga melahirkan "initial agreement" adalah ukuran keberhasilan kunci dalam mencapai tujuan (goals) suatu organisasi. Jadi, ke depan pendekatan kolaboratif menjadi esensi manajemen kebijakan publik, khususnya menyangkut pelayanan pendidikan yang dirasakan adil dan merata oleh masyarakat bangsa Indonesia ke depan.

4. Reformasi Lembaga Keuangan hubungan Pusat-Daerah

Perlu dilakukan penataan tentang hubungan keuangan antara Pusat -Daerah menyangkut pengelolaan pendapatan (revenue) dan penggunaannya (expenditure) untuk kepentingan pengeluaran rutin maupun pembangunan daerah dalam rangka memberikan pelayanan publik yang berkualitas. Sumber keuangan diperoleh dari Pendapatan Asli daerah, Dana perimbangan, pinjaman daerah dan lain-lain pendapatan yang syah Dengan melakukan pemerataan diharapkan dapat mendukung pelaksanaan kegiatan pada suatu daerah, terutama pada daerah miskin. Bila dimungkinkan dilakukan subsidi silang antara daerah yang kaya kepada daerah yang miskin, agar pemerataan pendidikan untuk mendapatkan kualitas sesuai dengan standar yang telah ditetapkan oleh pemerintah. Berbagai pengalaman menunjukkan bahwa sumber pendapatan tidak dapat digali secara optimal karena kondisi daerah, penaksiran tarif pajak yang tidak relevan dengan kondisi yang ada, petugas pajak yang kurang bertindak proaktif dan besarnya biaya operasional pemungutan. Hal ini akan memberi dampak dalam menentukan keberhasilan lembaga pendidikan, diakibatkan anggaran pendidikan yang terlalu kecil.

5. Kemauan Pemerintah Daerah melakukan Perubahan

Pada era otonomi, kualitas pendidikan sangat ditentukan oleh kebijakan pemerintah daerah. Bila pemerintah daerah memiliki political will yang baik dan kuat terhadap dunia pendidikan, ada peluang yang cukup luas bahwa pendidikan di daerahnya akan maju. Sebaliknya, kepala daerah yang tidak memiliki visi yang baik di bidang pendidikan dapat dipastikan daerah itu akan mengalami stagnasi dan kemandegan menuju pemberdayaan masyarakat yang well educated dan tidak pernah mendapat momentum yang baik untuk berkembang. Otonomi pendidikan harus mendapat dukungan DPRD, karena DPRD-lah yang merupakan penentu kebijakan di tingkat daerah dalam rangka otonomi tersebut. Di bidang pendidikan, DPRD harus mempunyai peran yang kuat dalam membangun pradigma dan visi pendidikan di daerahnya. Salah satu wujud kemauan politik pemerintah daerah otonomi adalah lahirnya peraturan daerah (Perda) tentang pendidikan sebagai payung pembangunan pendidikan yang berbasis lokal, bervisi nasional dan global. Oleh karena itu, badan legislatif harus diberdayakan dan memberdayakan diri agar mampu menjadi mitra yang baik. Kepala

RI'AYAH, Vol. 01, No. 02 Juli-Desember 2016 
pemerintahan daerah/ kota diberikan masukan secara sistematis dan berkelanjutan dalam membangun daerah. ${ }^{21}$

\section{Kesimpulan}

Desentralisasi pendidikan menempatkan sekolah sebagai garis depan dalam berperilaku untuk mengelola pendidikan. Desentralisasi juga memberikan apresiasi terhadap perbedaan kemampuan dan keberanekaragaman kondisi daerah dan rakyatnya. Perubahan paradigma sistem pendidikan membutuhkan masa transisi. Reformasi pendidikan merupakan realitas yang harus dilaksanakan, sehingga diharapkan para pelaku maupun penyelenggara pendidikan harus proaktif, kritis dan mau berubah. Belajar dari pengalaman sebelumnya yang sentralistik dan kurang demokratis membuat bangsa ini menjadi terpuruk. Marilah kita melihat kepentingan bangsa dalam arti luas dari pada kepentingan pribadi atau golongan atau kepentingan pemerintah pusat semata dengan menyelenggarakan otonomi pendidikan sepenuh hati dan konsisten dalam rangka mengangkat harkat dan martabat bangsa dan masyarakat yang berbudaya dan berdaya saing tinggi sehingga bangsa ini duduk sejajar dengan bangsa-bangsa maju di dunia.

\section{Daftar Pustaka}

Danim, Sudarwan. Visi Baru Manajemen Sekolah dari Unit Birokrasi ke Lembaga Akademik. Jakarta: PT Bumi Aksara, 2006.

Hasbullah. Otonomi Pendidikan: Kebijakan Otonomi Daerah Dan Implikasinya Terhadap Penyelenggaraan Pendidikan PT Raja Grafindo Persada: Jakarta, 2007.

Mulyasa, E. Manajemen Berbasis Sekolah, Konsep Strategi dan Implementasi, Bandung: Remaja Rosdakarya, 2012.

R. M. Suparman, Studi Pengembangan Kemampuan Dareah dalam Pendidikan, Jakarta: Balitbangdikbud, t.th.

Sujanto, Bedjo. Manajemen Pendidikan Berbasis Sekolah; Model Pengelolaaan Sekolah di Era Otonomi Daerah, Jakarta: Sagung Seto, 2007.

Tilaar, Manajemen Pendidikan Nasional, Kajian Pendidikan Masa Depan, Bandung: Remaja Rosda Karya.

Umiarso dan Imam Ghozali, Manajemen Mutu Sekolah di Era Otonomi Pendidikan, Jogjakarta: IRCiSoD, 2010.

Undang-Undang Nomor 32 Tahun 2004 tentang Pemerintahan Daerah dan Undang-Undang Nomor 20 Tahun 2003 tentang Sistem Pendidikan Nasional.

Undang-Undang No. 12 Tahun 2008 tentang Pemerintah Daerah.

Undang-Undang No. 33 Tahun 2004 tentang Perimbangan Keuangan antara Pemerintah Pusat dan Daerah. 